\title{
A gypsy moth (Lymantria dispar, Lepidoptera: Lymantriidae) multinucleocapsid nuclear polyhedrosis virus from France: comparison with a North American and a Korean strain
}

\author{
NeElam NARANG ${ }^{1}$, Franck HÉRARD ${ }^{2}$, EdWARD M. DOUGHERTY ${ }^{1}, \mathrm{KIM} \mathrm{CHEN}^{2}$ and Fernando E. VEGA*1 \\ ${ }^{1}$ Insect Biocontrol Laboratory, U. S. Department of Agriculture, Agricultural Research Service, Bldg. 011A, BARC-West, Beltsville, \\ Maryland 20705, USA \\ ${ }^{2}$ European Biological Control Laboratory, USDA, ARS, Campus International de Baillarguet, Montferrier-sur-Lez 34988, France
}

Key words. Biocontrol, microbial control, insect pathogens, baculovirus, NPV, nucleopolyhedrovirus, gypsy moth, Lymantria dispar, fluorescent brightener

\begin{abstract}
As part of a search for natural enemies of the gypsy moth (Lymantria dispar), virus-infected samples were collected near Toulouse, France. Light and electron microscope studies confirmed that the French strain is a multinucleocapsid nuclear polyhedrosis virus (MNPV). In vivo bioassays using the New Jersey strain of $L$. dispar, and comparing $L$. dispar MNPV (LdMNPV) strains from France, North America and Korea, showed that the French strain was the least active, whereas the North American strain had the highest activity. The viral efficacy of all strains was enhanced 200 to 1300 -fold in the presence of $1 \%$ fluorescent brightener. The enhancement was highest in the American strain and lowest in the French strain. French LdMNPV (LdMNPVF) DNA cut with four restriction enzymes (BamHI, EcoRI, HindIII, and NotI) revealed minor fragment size differences, but many similarities when compared to the North American and the Korean strain. PCR amplification of a LdMNPV early gene (G22) was detected in the North American and the Korean strain, but not in the French strain.
\end{abstract}

\section{INTRODUCTION}

Lymantria dispar multinucleocapsid nuclear polyhedrosis virus (LdMNPV) is known to be pathogenic to the gypsy moth, Lymantria dispar (L.), a common pest of oaks and other deciduous trees throughout the world. LdMNPV has been shown to contribute to the decline of gypsy moth populations and has been registered as a microbial insecticide in the United States (Lewis, 1981). Several strains of LdMNPV have been reported in the United States (Shapiro et al., 1984; Shapiro \& Dougherty, 1985; Shapiro \& Robertson, 1991). In Europe, LdMNPV has been reported in 7 European countries: Yugoslavia (Vasiljevic \& Injac, 1973, 1984; Maksimovic, 1978), Poland (Glowacka, 1983), Romania (Constantineanu \& Constantineanu, 1983; Mihalache et al., 1994), Italy (Luciano \& Prota, 1984), Switzerland (Wermelinger, 1995), Germany (Bogenschütz \& Kammerer, 1995; Wulf \& Graser, 1996), and France (Hérard et al., 1997). All collections of LdNPV in Europe were made when hosts were in outbreak situation, with epizootics leading to population collapse in most cases.

Even though LdMNPV is present in Europe, the gypsy moth is still considered a serious pest. For example, from 1990 through 1995, the gypsy moth developed outbreaks in 16 countries almost simultaneously: Austria (Hoch \& Schopf, 1995), Czech Republic (Švestka, 1994), England (Baker et al., 1996), France (Hérard et al., 1997), Germany (Wulf \& Graser, 1996), Hungary (Csoka, 1996), Italy (Lentini \& Luciano, 1995), The Netherlands (Moraal,
1996), Poland (Lipa \& Kolk, 1995), Portugal (de Sousa \& Luciano, 1995), Romania (Mihalache et al., 1994), Russia (Rubstov, 1996), Serbia (Mihajlovic et al., 1998), Slovakia (Novotny \& Turcani, 1997), Spain (Roy et al., 1995), and Switzerland (Wermelinger, 1995).

In June of 1998 virus-infected samples of $L$. dispar larvae were found in an oak forest around Pujaudran, 20 $\mathrm{km}$ west of Toulouse, France, in a population that was increasing 5 years after a previous outbreak. In this area, several portions of the Forêt de Bouconne had suffered gypsy moth attacks of various intensities between 1990 and 1993 (Hett, 1995). Our study was designed to compare the virulence of the French virus to other $L$. dispar strains from North America and Asia (Korea), as well as to partially characterize the French virus. These studies will increase knowledge concerning geographical variation in LdMNPV and may eventually help to select the most virulent strain for the biological control of gypsy moth.

\section{MATERIALS AND METHODS}

\section{Specimen collection}

Gypsy moth larvae were collected in an oak forest [Quercus robur L. and Quercus petraea (Mattuschka) Lieblein] near Pujaudran (Gers), $20 \mathrm{~km}$ west of Toulouse (Haute-Garonne), France in June of 1998. Specimens were collected on tree trunks and on foliage at chest height and placed individually in $116 \mathrm{ml}$ plastic cups on simplified high wheat germ diet (Bell et al., 1981). Insects were maintained in the laboratory at $24 \pm 1^{\circ} \mathrm{C}, 70$ $\pm 10 \% \mathrm{RH}$, and a photoperiod of $18 \mathrm{~L}: 6 \mathrm{D}$ until death, or the

\footnotetext{
* Address correspondence to: Dr. Fernando E. Vega, USDA, ARS, Insect Biocontrol Laboratory, Bldg. 011A, Room 214, BARCWest, Beltsville, Maryland 20705, USA; e-mail: vegaf@ba.ars.usda.gov
} 
emergence of a parasitoid or a moth. The number of larvae collected were 1,101 on June 14 and 1,383 on June 21, 1998.

\section{Virus extraction}

The presence of occlusion bodies (OBs) in dead larvae suspected to be virus- infected was confirmed by light microscopy. For comparative purposes, a North American strain, i.e. the Abington strain of LdMNPV (LdMNPV-Ab-a624; henceforth referred to as a624; Lynn et al., 1993) and a Korean LdMNPV strain (LdMNPVK; provided by M. Shapiro, USDA) were used. Tompkins (1991) method with minor modifications was used for viral purification. In summary, the virus-infected $L$. dispar cadavers were blended in a homogenizer (Virtis Research Equipment, Gardiner, New York, USA) with distilled water and strained through four layers of cheese cloth. All of the centrifugations were performed in a refrigerated Sorvall-RC-5B centrifuge (Sorvall Products, L.P., Newtown, Connecticut, USA) using a SS-34 rotor (DuPont Instruments, Wilmington, Delaware, USA). The mixture was centrifuged at $3000 \mathrm{rpm}$ for 15 minutes. The pellet was re-suspended in distilled water and centrifuged again at $3000 \mathrm{rpm}$ for 15 minutes followed by resuspension in $10 \mathrm{ml}$ of distilled water and sonicated (Branson Sonifier, VWR Scientific, Westchester, Pennsylvania, USA) at the medium setting. The suspension was then layered on a bed of $40 \%(\mathrm{w} / \mathrm{w})$ sucrose solution and centrifuged at $8500 \mathrm{rpm}$ for one hour. The pellet was suspended and sonicated again and layered on a $40-65 \%$ sucrose gradient and centrifuged at 20,000 $\mathrm{rpm}$ for 60 minutes. OBs were collected and washed in 1\% SDS and $0.5 \mathrm{mg} / \mathrm{ml}$ proteinase $\mathrm{K}$ for $2-3$ hours at room temperature. The pellet containing OBs was washed with distilled water three times and suspended in a small volume of distilled water; OBs were visually counted using a Neubauer hemacytometer.

\section{Electron microscopy}

Adams et al. (1977) methodology for OB's preparation and examination was followed. In summary, the OBs were fixed in sodium cacodylate buffer, $\mathrm{pH} 7.2(0.05 \mathrm{M}$ sodium cacodylate, $0.5 \mathrm{mM} \mathrm{HCl}$ ) with $0.17 \mathrm{M}$ sucrose and $2.5 \%$ glutaraldehyde at $4^{\circ} \mathrm{C}$ overnight. The samples were washed three times in $0.05 \mathrm{M}$ sodium cacodylate buffer with $0.34 \mathrm{M}$ sucrose at $4^{\circ} \mathrm{C}$ followed by fixation in $1 \%$ osmium tetroxide at $4^{\circ} \mathrm{C}$ for two hours and three washes with sodium cacodylate buffer without sucrose. Samples were stained with $2 \%$ uranyl acetate (aqueous) at $4{ }^{\circ} \mathrm{C}$ for 45 minutes and rinsed in sodium cacodylate buffer followed by centrifugation at $3,000 \mathrm{~g}$ for 5 minutes. The pellet was then dehydrated through a series of alcohol concentrations $30 \%$, $50 \%, 70 \%, 95 \%$ and $100 \%$ ) for 15 minutes in each and then cut into small pieces and infiltrated in a propylene oxide:epon 812 mixture $(1: 1)$ for one hour followed by infiltration with propylene oxide and epon $812(1: 3)$ mixture. The samples were finally infiltered in epon 812 for 8 hours and then incubated at $60^{\circ} \mathrm{C}$ overnight. Thin sections were cut using a diamond knife and an LKB ultra microtome (LKB Produkter AB, Bromma, Sweden). The grids were stained with $2 \%$ uranyl acetate and lead citrate, examined using a Philips $400 \mathrm{~T}$ electron microscope (FEI Co., Hillsboro, Oregon, USA) and photographed. A sample of 200 cross sections of $O B$ s from each of the three strains were photographed. The diameter of each $O B$ cross section was measured and the number of virions in each cross section was counted.

\section{In vivo bioassays}

The three virus strains were fed to the New Jersey strain of $L$. dispar (USDA- APHIS, Otis Air National Guard Base, Massachusetts, USA) and the virus extracted (using Tompkins method (1991) as previously described) for use in bioassays. The virulence (measured as the virus amount required for $50 \%$ effective lethal concentration, or $\mathrm{LC}_{50}$ ) of the three LdMNPV strains was determined using the techniques of Shapiro \& Argauer (1995). The New Jersey strain of $L$. dispar was used for bioassays.

To test whether fluorescent brighteners would enhance viral activity, as has been previously reported (Shapiro \& Robertson, 1992; Dougherty et al. 1995), serial dilutions of eight concentrations of the stock OBs suspensions were prepared either in distilled water or in $1 \%$ (wt/wt) fluorescent brightener 28 (Calcofluor white M2R, Sigma Chemical Co., St. Louis, Missouri, USA). One milliliter of the viral suspensions was applied to the diet surfaces $(90 \mathrm{ml}$ of diet in a $180 \mathrm{ml}$ cup) at concentrations ranging from $10^{1}$ to $10^{8} \mathrm{OBs} / \mathrm{ml}$ per cup. Each diet cup contained ten 2nd instar larvae. Two cups of controls were used in each set, one containing water and the other $1 \%(\mathrm{wt} / \mathrm{wt})$ fluorescent brightener 28 . Tests were repeated six times for each concentration, with three replicates per treatment each time. Larvae were reared in a growth chamber at $29 \pm 2^{\circ} \mathrm{C}$ under a $12 \mathrm{~L}: 12 \mathrm{D}$ cycle at $50 \% \mathrm{RH}$ and were observed from day 1 to day 14. Dead larvae were counted and dosage-mortality data was determined using Probit analysis (Russell et al., 1977).

\section{Molecular analyses \\ Extraction of DNA from OBs}

Viral DNA was extracted using Loh's et al. (1981) procedure. The OB's were re-suspended in an extraction buffer consisting of $0.14 \mathrm{M} \mathrm{NaCl}, 0.03 \mathrm{M} \mathrm{KCl}, 0.01 \mathrm{M} \mathrm{Na}_{2} \mathrm{HPO}_{4}, 2 \mathrm{mM} \mathrm{KH}_{2} \mathrm{PO}_{4}$ (pH 7.4), 1\% SDS, 0.08 M EDTA ( $\mathrm{pH} 8.0$ ) The proteins were digested by adding $500 \mu \mathrm{g} / \mathrm{ml}$ of proteinase $\mathrm{K}$ and incubated for one hour at $37^{\circ} \mathrm{C}$. $\mathrm{Na}_{2} \mathrm{CO}_{3}(\mathrm{pH} 10.6)$ was added to a final concentration of $0.1 \mathrm{M}$, and the solution was then incubated at $37^{\circ} \mathrm{C}$ for one hour. The DNA was extracted with 1 volume buffered phenol, 2 volumes of chloroform:isoamyl alcohol (24:1), and then precipitated with 2 volumes of cold ethanol. The precipitate was dissolved in $1 \mathrm{mM}$ Tris, $0.01 \mathrm{mM}$ EDTA buffer ( $\mathrm{pH} 7.5$ ).

\section{Analysis of virus DNA with restriction endonucleases}

The viral DNA was digested with four restriction enzymes (BamHI, EcoRI, HindIII and NotI) using standard protocols (Miller \& Dawes, 1978 ; Sambrook et al., 1989) at $37^{\circ} \mathrm{C}$ for two hours. The samples were then analyzed by electrophoresis in a $0.8 \%$ agarose gel and stained with $0.5 \mu \mathrm{g} / \mathrm{ml}$ ethidium bromide. The DNA bands were visualized using a UV transilluminator.

\section{PCR amplification using early gene (G22) primers}

The forward primer (5' CGC ACC GCG TCC ACG ATA ACG AGC GC 3') homologous to nucleotides 191-216 and reverse primer (5' ACA TGG TCG TGC CCG ACC AGT CGT AA 3') complementary to nucleotides 716-741 were designed from a published sequence of an early gene (G22) in LdMNPV (Bischoff \& Slavicek, 1995). The primers were synthesized by BRL (Gibco/BRL, Gaithersburg, Maryland, USA). The reaction was carried out in a final volume of $50 \mu 1$ consisting of $20 \mathrm{mM}$ Tris HCl, $50 \mathrm{mM} \mathrm{KCl} \mathrm{(pH} \mathrm{8.0),} 2.5 \mathrm{mM} \mathrm{MgCl}_{2}, 200 \mu \mathrm{M}$ each of the four deoxynucleotide triphosphates, 20 pmols of each primer and 2.5 units of Taq polymerase (Gibco/BRL, Gaithersburg, Maryland, USA). The mixture was subjected to 35 cycles of amplification in a OMNI-E thermocycler (Hybaid, Middlesex, UK) as follows: denaturation at $94^{\circ} \mathrm{C}$ for one minute, annealing at $55^{\circ} \mathrm{C}$ for two minutes and extension at $72^{\circ} \mathrm{C}$ for three minutes. The template used was from LdMNPVF, a624, LdMNPVK, and LdMNPV-ßgal (a recombinant virus containing a $ß$-galactosidase gene under the control of the late polyhedrin promotor; provided by J.M. Slavicek, USDA Forest Service). The amplified product $(5 \mu 1)$ was analyzed by electrophoresis using $0.8 \%$ agarose gel and visualized using a UV transilluminator. 


\section{RESULTS AND DISCUSSION}

The percentages of gypsy moths surviving to adult stage were $44.2 \%$ and $37.2 \%$ in samples collected on 14 and 21 June, 1998, respectively; mortality due to NPV infection was $31.7 \%$ and $50.1 \%$ and total parasitism was $24.1 \%$ and $12.7 \%$, on samples collected on 14 and 21 June, respectively. Five parasitoid species were obtained: two braconids (Glyptapanteles porthetriae Muesebeck and Cotesia melanoscela (Ratzeburg)) and 3 tachinids (Compsilura concinnata (Meigen), Blepharipa pratensis (Meigen), and Parasetigena silvestris (RobineauDesvoidy)). The most abundant species was P. silvestris, obtained from $21.1 \%$ and $10.4 \%$ of the gypsy moths collected on 14 and 21 June, respectively.

There are two morphological types of baculoviruses: a single nucleocapsid virus (SNPV), where only one nucleocapsid is found in each virion, and a multiple nucleocapsid (MNPV), in which a virion may contain numerous nucleocapsids. By employing both light and electron microscopy, our study confirms that the French strain belongs to the MNPV. The LdMNPVF strain showed characteristic polyhedral, proteinaceous inclusion bodies in the infected cells, which is a unique feature of the Baculoviridae, subgroup A (Bilimoria, 1991). Electron micrographs of the cross section of $O B s$ from LdMNPVF revealed bundles of virions in the nucleocapsids (Fig. 1A). The average diameter of the cross section of OBs was $2.1 \pm 0.06 \mu \mathrm{m}$ in LdMNPVF, $1.99 \pm 0.04 \mu \mathrm{m}$ in a 624 and $1.5 \pm 0.06 \mu \mathrm{m}$ in LdMNPVK (Figs $1 \mathrm{~A}, \mathrm{~B}, \mathrm{C}$ ). The average size of the cross section of OBs of LdMNPVF was significantly larger than in LdMNPVK ( $p<0.001$ ), but there was no significant difference from a624. However, the number of virions/cross section of OBs in LdMNPVF and LdMNPVK (16.25 \pm 0.9 and $16.2 \pm 1.39$, respectively) were significantly lower $(\mathrm{p}<$

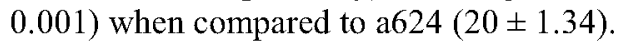

In the present study, the $\mathrm{LC}_{50}$ of LdMNPVF was the highest $\left(1.5 \times 10^{4} \pm 1797 \mathrm{OBs} / \mathrm{ml}\right)$ in contrast to $\mathrm{a} 624$, which had the lowest $\mathrm{LC}_{50}\left(1.6 \times 10^{3} \pm 190 \mathrm{OBs} / \mathrm{ml}\right)$. The $\mathrm{LC}_{50}$ of LdMNPVK was $3.9 \times 10^{3} \pm 890 \mathrm{OBs} / \mathrm{ml}$ (Fig. 2); bioassays using LdMNPVK had not been previously reported. Previous studies of comparative infectivities of LdMNPV strains from North America, Europe and Asia showed that the $\mathrm{LC}_{50}$ values varied from $1.7 \times 10^{3} \mathrm{OBs} / \mathrm{ml}$ to greater than $5 \times 10^{6} \mathrm{OBs} / \mathrm{ml}$ (Shapiro et al., 1984; Shapiro \& Dougherty, 1985). Comparison of five LdMNPV strains from France, Yugoslavia, Italy, United States and Japan showed greater than 1000-fold activity differences among the various strains (Magnoler, 1970); Shapiro et al. (1984) demonstrated 2900-fold differences in $\mathrm{LC}_{50}$ among 19 isolates from Asia, Canada, Europe and the USA. Our data is in agreement with previous results (Shapiro \& Dougherty, 1985) showing less activity in European and Asian strains when compared to a624, although it should be noted that results might vary from ours when other strains of gypsy moth are used. Magnoler (1970) has also reported high activity from a USA strain when compared to strains from France and Japan.
The feeding of $L$. dispar larvae with the French strain of LdMNPV showed that there was about 200 -fold enhancement of the viral efficacy in the presence of $1 \%$ fluorescent brightener 28 (LdMNPVF alone $=1.5 \times 10^{4} \pm$ $1797 \mathrm{OBs} / \mathrm{ml}$; with brightener $=82 \pm 14 \mathrm{OBs} / \mathrm{ml}$; Fig. 2);
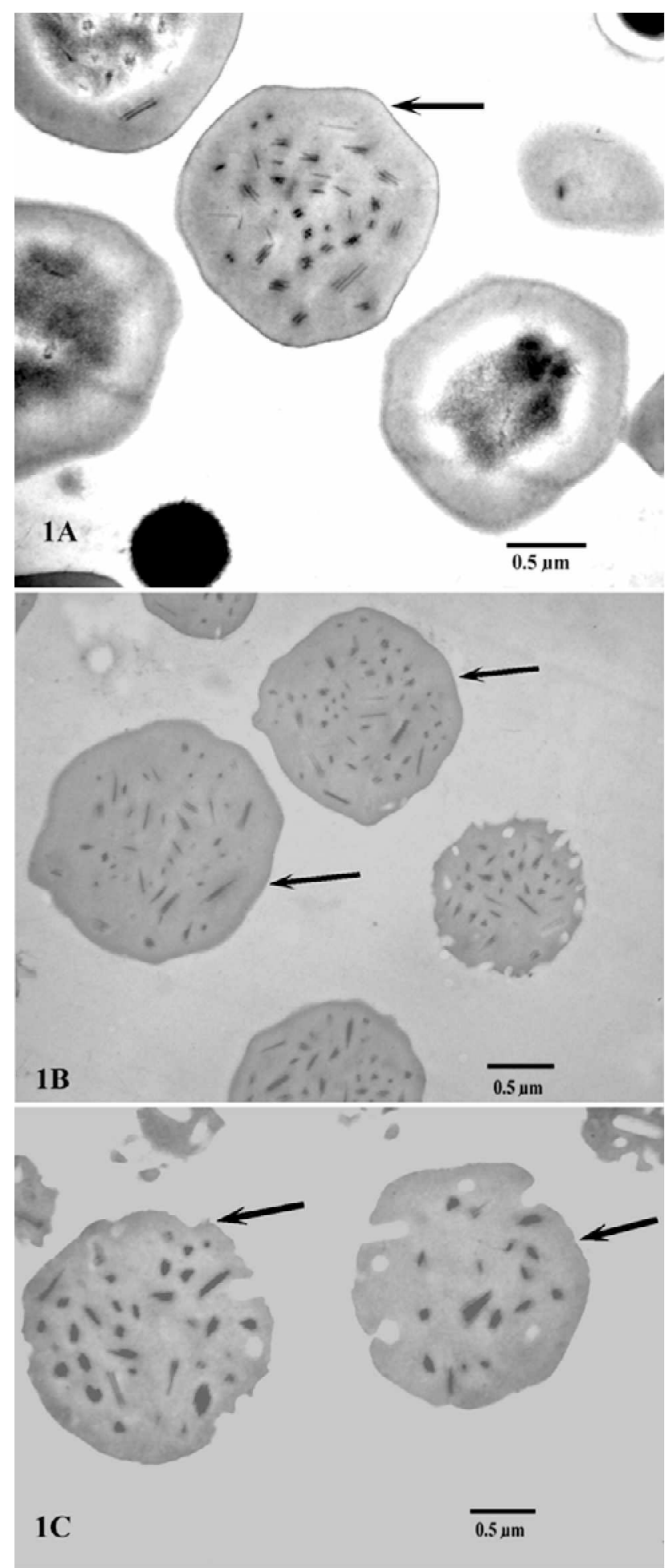

Fig. 1. Electron micrograph of the cross section of several purified occlusion bodies (OBs) isolated from LdMNPVF (1A). Figs. $1 \mathrm{~B}$ and $1 \mathrm{C}$ show a representative number of $\mathrm{OBs}$ isolated from LdMNPVK and a624, respectively. 


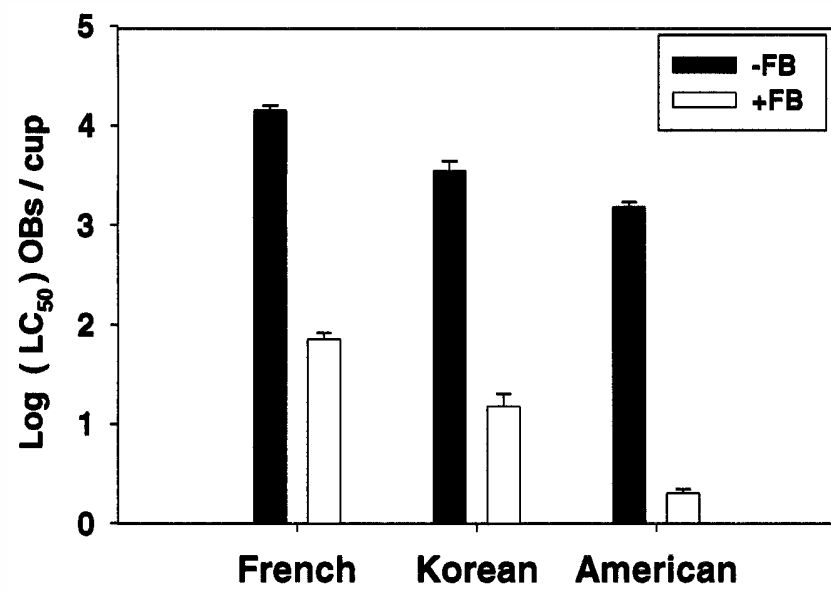

Fig. 2. Comparison of $\log \mathrm{LC}_{50}$ among LdMNPV isolates from France, Korea and North America. LdMNPVF is least active when compared to North American and Korean isolates. Note the large decrease in $\log \mathrm{LC}_{50}$ of the larvae fed with LdMNPV with $1 \%$ fluorescent brightener 28 in all three viruses isolates.

however the American strain showed 1300-fold increase (a624 alone $=1.6 \times 10^{3} \pm 190 \mathrm{OBs} / \mathrm{ml}$; with brightener $=$ $1.20 \pm 0.39 \mathrm{OBs} / \mathrm{ml}$; Fig. 2) and the Korean strain a $400-$

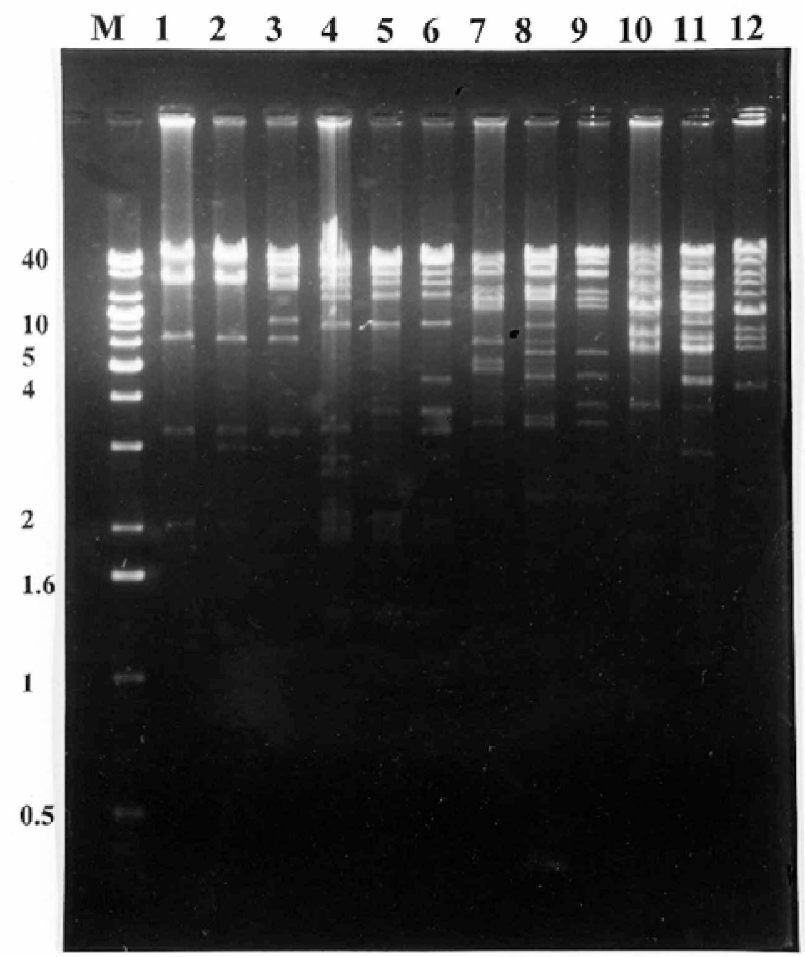

Fig. 3. Genomic DNA digests of a624, LdMNPVK and LdMNPVF. Viral DNA was digested with restriction endonucleases BamH1 (1, 2, 3), HindIII (4, 5,6), EcoR1 (7, 8, 9), and Not $1(10,11,12)$. Samples were subjected to electrophoresis in $0.8 \%$ agarose, stained with ethidium bromide, and photographed. Lanes 1, 4, 7 and 10 contain fragments from a624, lanes 2, 5, 8, and 11 from LdMNPVK and lanes 3, 6, 9 and 12 from LdMNPVF. Lane M shows the DNA size markers (in kilobase pairs). fold increase $\left(\mathrm{LdMNPVK}\right.$ alone $=3.9 \times 10^{3} \pm 890 \mathrm{OBs} / \mathrm{ml}$; with brightener $=10 \pm 0.77 \mathrm{OBs} / \mathrm{ml}$; Fig. 2). It is clear that fluorescent brightener 28 enhances viral activity, as has been previously reported (Shapiro and Robertson, 1992; Shapiro \& Dougherty, 1993, 1994; Dougherty et al., 1995 ); the addition of brighteners to LdMNPV have reduced the average $\mathrm{LC}_{50} 400-1800$ fold (Shapiro \& Dougherty, 1993).

Comparisons of restriction endonuclease fragment profiles is an important tool to identify molecular differences among various viral species and strains ( Smith \& Summers, 1978; McCarthy et al., 1979; Maruniak et al., 1984; Cherry \& Summer, 1985; Shapiro \& Dougherty, 1985; Kuzio et al., 1999). The viral genome DNA of LdMNPVF, a624, and LdMNPVK digested with BamHI, EcoRI, HindIII, and NotI showed similarities (Fig. 3) among all the major group of fragments present in all three strains. There were, however, differences in some of the fragment sizes among three strains. The general pattern profile agrees with previous studies (McCarthy et al., 1979; McClintock \& Dougherty, 1988) where LdMNPV DNA was digested with BamH1, EcoR1 and Hind III.

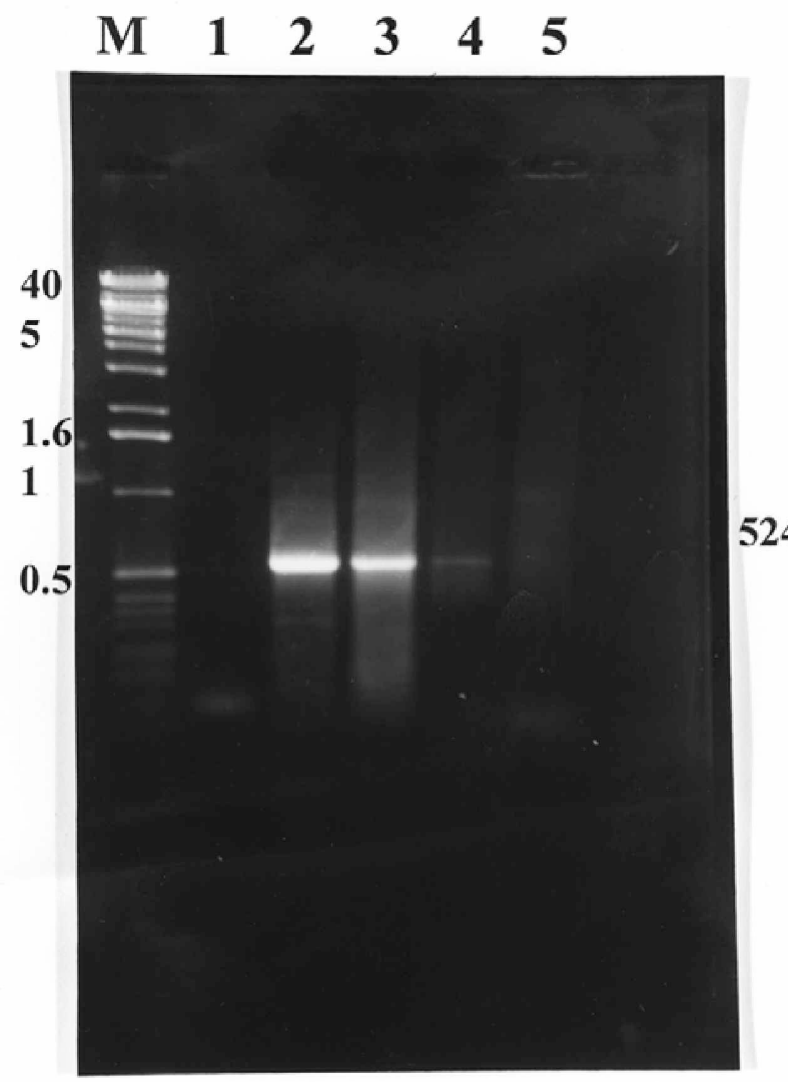

Fig. 4. PCR amplification of early gene (G22) sequence from LdMNPV using DNA templates of a624 (lane 2), LdMNPV $\beta$-gal (lane 3), LdMNPVK (lane 4) and LdMNPVF (lane 5). Lane 1 is from a healthy $L$. dispar cell line (control). The amplified product of 524 base pairs was evident in a624 (lane 2 ) and LdMNPV $\beta$-gal (lane 3), whereas the LdMNPVK showed a very faint product (lane 4). No amplified product could be seen with the LdMNPVF template or in the control. Lane $\mathrm{M}$ is the $40 \mathrm{~Kb}$ marker. 
However, there are more minor fragments present when the French isolate was digested with $B a m \mathrm{H} 1$.

PCR has been useful to detect various baculoviruses (Moraes \& Maruniak, 1997). Using this technique, it is possible to detect the amplified gene of interest in various viral strains and thus to distinguish similarities among various populations or strains. In the present study, a 524 base pair fragment found in an early gene (G22) of LdMNPV amplified when DNA from a624, LdMNPV- $3-$ gal, and LdMNPVK strains were used (Fig. 4). However, there was no amplification of the early gene fragment when LdMNPVF was used, perhaps due to a primer mismatch in the 3' end. Future studies using hybridization probes for this gene will determine if it is present or absent in the French strain.

Our study shows that the French isolate of LdMNPV is the least virulent among the three strains, and that fluorescent brighteners enhance viral efficacy. In addition, LdMNPVF has many similarities to North American and Korean LdMNPV strains based on restriction enzyme analysis, although there was no amplification, using PCR, of an early gene (G22) in the French strain.

ACKNOWLEDGEMENTS. We are grateful to Jean R. Adams (USDA) for her expert assistance with electron microscopy and Martin Shapiro (USDA) for providing $L$. dispar larvae, LdMNPVK, and for reviewing a previous version of this manuscript. Also, J.M. Slavicek (USDA Forest Service) for providing a recombinant LdMNPV- $\beta$-gal virus. Names are necessary to report factually on available data; however, the USDA neither guarantees nor warrants the standard of the product, and the use of the name by USDA implies no approval of the product to the exclusion of others that may also be suitable.

\section{REFERENCES}

Adams J.R., Goodwin R.H. \& Wilcox T.A. 1977: Electron microscope investigations on invasion and replication of insect baculoviruses in vivo and in vitro. Biol. Cell 28: 261-263.

BAKER R.H., GraY D.R. \& Walters K.F.A. 1996: Assessing the risk posed by some forest insect pests to the United Kingdom. In: Proceedings XX International Congress of Entomology, Firenze, Italy, Aug 25-31, 504 pp.

Bell R.A., Owens C.D., Shapiro M. \& TardifF J.R. 1981: Development of mass-rearing technology. In Doane C.C. \& McManus M.L. (eds): The Gypsy Moth: Research Toward Integrated Pest Management, USDA - FS, Tech. Bull. 1584: $599-655$.

BiLIMORia S.L. 1991: The Biology of Nuclear Polyhedrosis Viruses. In Kurstak E. (ed): Viruses of Invertebrates. Marcel Dekker Inc, New York, pp. 1-72.

Bischoff D.S. \& SLAviceK J.M. 1995: Identification and characterization of an early gene in the Lymantria dispar multinucleocapsid nuclear polyhedrosis virus. J. Gen. Virol. 76: 2933-2940.

Bogenschưtz H. \& Kammerer M. 1995: Studies on the population dynamics of the gypsy moth, Lymantria dispar (Lepidoptera, Lymantriidae), in Baden-Wurttemberg. Mitt. Dtsch. Ges. Allg. Angew. Entomol. 10: 113-117.

Cherry C.L. \& Summer M.D. 1985: Genotype variation among wild isolates of two nuclear polyhedrosis viruses isolated from Spodoptera littoralis. J. Invertebr. Pathol 46: 289-295.
Constantineanu I. \& Constantineanu R. 1983: The parasite complex of gypsy moth (Lymantria dispar L.) (Lepidoptera: Lymantriidae) in the oak woods from southern Romania. Rev. Roum. Biol. Ser. Biol. Animale 28: 85-89.

CsoKA G. 1996: Drought years - increasing damage by insect pests in Hungarian forests. Novenyvedelem 32: 545-551.

Dougherty E.M., Guthrie K. \& ShaprRo M. 1995: In vitro effects of fluorescent brightener on the efficacy of occlusion body dissolution and polyhedral-derived virions. Biol. Control 5: 383-388.

GLOWACKA B. 1983: Role of pathogens in the course of gradation of the common Lymantria dispar L. on Biebrza-swamps. Pr. Inst. Badaw. Lesn. Warszawa: Panstwowe Wydawn. Rolnicze i Lesne 608/612: 29-42.

Hérard F., Chen K. \& Cameron E.A. 1997: Natural enemy impact on gypsy moth in Alsace, France, during 1995. In Fosbroke S.L.C. \& Gottschalk K.W. (eds): Proceedings, USDA Interagency Gypsy Moth Research Forum 1996, Annapolis, MD, Jan. 16-19, 1996. USDA-Forest Service, General Technical Bulletin NE-230, 39 pp.

Hetт P. 1995: Le Bombyx disparate: une fin de gradation. In: La Santé des Forêts (France) 1994, Ministère de l'Agriculture, de la Pèche et de l'Alimentation, Direction de l'Espace Rural et de la Forêt. Département de la Santé des Forêts, Paris, pp. 16-18.

Hoch G. \& Schopf A. 1995: Der Parasitoidenkomplex des Schwammspinners Lymantria dispar L. (Lep., Lymantriidae) in Populationen hoher, mittlerer und niederer Dichte im Burgenland. Mitt. Dtsch. Ges. Allg. Angew. Entomol. 10: 195-198.

Kuzio J.M., Pearson N., Harwood S.H., Funk C.J., Evans J.T., SlaniceK J.M. \& RohrmanN G.F. 1999: Sequence and analysis of the genome of baculovirus pathogenic for Lymantria dispar. Virology 253: 17-34.

Lentini A. \& Luciano P. 1995: Bacillus thuringiensis in the management of gypsy moth (Lymantria dispar L.) in Sardinian cork-oak forests. In Luciano P. (ed.): Integrated Protection in Cork-Oak Forests. Tempio Pausania, Italy, pp. 104-109.

LEWIS F.B. 1981: Control of the gypsy moth by a baculovirus. In Burges H.D. (ed.): Microbial Control of Pests and Plant Diseases 1970-1980. Academic Press, London, pp. 363-377.

L.PA J.J. \& KolK A. 1995: The recent situation of the gypsy moth (Lymantria dispar) and other lymantriids in Poland. Bulletin OEPP 25: 623-629.

LoH L.C., HAMM J.J. \& HUANG E. 1981: Spodoptera frugiperda nuclear polyhedrosis virus genome: physical map for restriction endonucleases BamHI and HindIII. J. Virol. 38: 922-931.

Luciano P. \& Prota R. 1984: La dinamica di popolazione di Lymantria dispar L. in Sardegna. III. Indicatori biologici della gradazione. Frustula Entomologica 7-8: 613-630.

LynN D.E., Shapiro M. \& Dougherty E.M. 1993: Selection and screening of clonal isolates of the Abington strain of gypsy moth nuclear polyhedrosis virus. J. Invertebr. Pathol. 62:191-195.

MAgnoler A. 1970: Susceptibility of gypsy moth larvae to Lymantria sp. nuclear and cytoplasmic viruses. Entomophaga 15: 407-412.

MaKsmovic M. 1978: Some research on the relation between the population densities of the gypsy moth and its natural enemies. Zast. Bilja 143/144: 127-139.

Maruniak J.E. , Brown S.E. \& Knudson D.L. 1984: Physical maps of SfMNPV baculoviruses DNA and its genomic variants. Virology 136: 221-234. 
McCarthy W.J., Murphy T.F. \& LangRidge W. 1979: Characteristics of the DNA from Lymantria dispar nuclear polyhedrosis virus. Virology 95: 593-597.

MCClintock J.T. \& Dougherty E.M. 1988: Restriction mapping of Lymantria dispar nuclear polyhedrosis virus DNA: localization of the polyhedrin gene and identification of four homologous regions. J. Gen. Virol. 69: 2303-2312.

Mriajlovic L., Grbic P. \& VANDIC D. 1998: The latest outbreaks of gypy moth Lymantria dispar L. (Lepidoptera, Lymantriidae) in the region of Serbia in the period 19951998. Acta Entomol. Serbica, Suppl. Special Issue: 80-88.

Mihalache G., Tomescu R. \& Fratian A. 1994: Experiments with the microbiological control of forest defoliators carried out in Romania during 1993-1994. In: Biological and Integrated Forest Protection. Proceedings of the international symposium, Sekocin, Poland Sept. 12-16, 1994, pp. 45-55.

Miller L.K. \& DaWes K.P. 1978: Restriction endonucleases analysis for the identification of baculovirus pesticides. Appl. Envir. Microbiol. 35: 411-421.

MorAAL L.G. 1996: 50 jaar monitoring van insectenplagen op bomen en struiken. In bosssen, natuurgebieden en wegbeplantigen. Nederlands Bosbouw Tidschr. 68:194-203.

Moraes R.R. \& MARUNIAK J.E. 1997: Detection and identification of multiple baculoviruses using the polymerase chain reaction (PCR) and restriction endonuclease analysis. J. Virol. Meth. 63: 209-217.

NovotnY J. \& TURCANI M. 1997: A new strategy for the ecological control of the gypsy moth (Lymantria dispar, Lepidoptera). Biologia (Bratislava) 52: 337-341.

Roy A.S., MCNamara D.G. \& SMITH I.M. 1995: Situation of Lymantria dispar in Europe. Bulletin OEPP 25: 611-616.

RuBTsov V.V. 1996: Influence of repeated defoliations by insects on wood increment in common oak (Quercus robur L.). Anls. Sci. Forest. 53: 407-412.

Russell R.M., Robertson J.L. \& SAvin N.E. 1977: POLO: A new computer program for Probit analysis. Bull. Entomol. Soc. Am. 23: 209-213.

SAMBrook J., Fritsch E.F. \& Maniatis T. 1989: Molecular Cloning: A Laboratory Manual, $2^{\text {nd }} e d$. Cold Spring Harbor Laboratory Press, New York.

Shapiro M., Robertson J.L., Injac M.G., Katagiri K. \& Bell R.A. 1984: Comparative infectivities of gypsy moth (Lepidoptera: Lymantriidae) nucleopolyhedrosis virus isolates from North America, Europe, and Asia. J. Econ. Entomol. 77: 153-156.

SHAPIRO M. \& DOUGHERTY E.M. 1985: Selection of active strains of the gypsy moth nuclear polyhedrosis virus. Symposium: Microbial Control of Spruce Budworms and Gypsy Moths. USDA, Northeast Forest Experiment Station, Broomall, PA. GTR-NE-100, pp. 115-122.
Shapiro M. \& RoberTson J.L. 1991: Natural variability of three geographic isolates of gypsy moth (Lepidoptera: Lymantriidae) nuclear polyhedrosis virus. J. Econ. Entomol. 84: 71-75.

SHAPIRO M. \& Robertson J.L. 1992: Enhancement of gypsy moth (Lepidoptera: Lymantriidae) baculovirus activity by optical brighteners. J. Econ. Entomol. 85: 1120-1124.

Shapiro M. \& Dougherty E.M. 1993: The use of fluorescent brightener as activity enhancers for insect pathogenic viruses. In Lumsden R.D. \& Vaughan J.L. (eds): Pest Management: Biologically Based Technologies. American Chemical Society, Washington D.C., pp. 40-46.

SHAPIRO M. \& DOUGHERTY E.M. 1994: Enhancement in activity of homologous and heterologous viruses against the gypsy moth (Lepidoptera: Lymantriidae) by an optical brightener. $J$. Econ. Entomol. 87: 361-365.

Shapiro M. \& ARgaUer R. 1995: Effect of pH, temperature and ultraviolet radiation on the activity of an optical brightener as a viral enhancer for the gypsy moth (Lepidoptera: Lymantriidae) baculovirus. J. Econ. Entomol. 88: 1602-1606.

SMith G.E. \& Summers M.D. 1978: Analysis of baculovirus genomes with restriction endonucleases. Virology 89: $517-527$.

SousA DE E.M.R. \& LuClANO P. 1995: Les principaux ravageurs du chene liege au Portugal: leurs relations avec le declin des peuplements. Proceedings of the Meeting on Integrated Protection in Cork-oak Forests, Tempio Pausania (Italy), 15-17 September 1994. Bulletin OILB SROP. 18: 18-23.

ŠvestKA M. 1994: Ohlédnutí za gradací bekyně velkohlavé.[Outbreak of Lymantria dispar L.] Lesnická Práce 73: 5-7.

Tompkins G.J. 1991: Purification of invertebrate viruses. In Adams J.R. \& Bonami J.R. (ed.): Atlas of Invertebrate Viruses, CRS Press, Boca Raton, Florida, pp. 31-40.

VASILJEVIC L. \& INJAC M. 1973: A study of gypsy moth viruses originating from different geographical regions. Plant Protection 24: 169-186.

VASILJEVIC L. \& INJAC M. 1984: Influence des maladies virales sur le dynamisme des populations de Lymantria dispar L. et Hyphantria cunea Drury en Yougoslavie. Bull. Soc. Entomol. Fr. 89: 800-807.

Wermelinger B. 1995: Massenvermehrung und Populationszusammenbruch des Schwammspinners Lymantria dispar L. (Lymantriidae) 1992/93 im Tessin. Mitt. Schweiz. Entomol. Ges. 68: 419-428.

WulF A. \& Graser E. 1996: Gypsy moth outbreaks in Germany and neighboring countries. Nachr. Deut. Pflanzsch. 48: 265-269.

Received June 5, 2000; revised September 12, accepted October 5, 2000 